\title{
Reparations revisited: the role of economic advisers in reforming German central banking and public finance
}

\author{
ROBERT YEE \\ Princeton University
}

\begin{abstract}
The economic advisers of the 1924 Dawes Committee enacted currency and banking reforms as a means of resolving financial and geopolitical problems. Although the committee members stated that they had no plans to resolve the Ruhr occupation, evidence from the technical advisers demonstrated the opposite. Economists Edwin Kemmerer, Joseph Davis and Arthur Young sought to appease Franco-Belgian demands for a resolution to the reparations debate by balancing the German budget and reorganising the banking system, thereby also addressing the question of military occupation. This research delves into the advisers' reports on public finance, currency stabilisation and the gold standard, arguing that their attempts to assuage reparation-related concerns rested on major reforms to German central banking.
\end{abstract}

Keywords: reparations, financial reform, European history, central banking

JEL classification: $\mathrm{E}_{5} 8, \mathrm{~F}_{3} \mathrm{O}, \mathrm{F}_{34}, \mathrm{~N}_{24}$

In January 1926, S. Parker Gilbert, an American lawyer and the Agent General for Reparation Payments, addressed the Council on Foreign Relations on the plan to resolve German debts from World War I. He commented on the success of the Dawes Plan, a series of measures, recommendations and proposals for the payment of these reparations through the Transfer Office, of which Gilbert was the head. Over a year had passed since the governments of the Allied Powers and Germany accepted the terms of the agreement at the London Conference in August I924. Gilbert thus recounted the intentions of the Dawes Committee from a historical perspective: 'Germany was on the verge of collapse, after an unprecedented period of inflation ... conditions grew steadily worse until they reached a crisis in the fall of I923' (I926, pp. ii-iii). Following the Franco-Belgian occupation of the Ruhr,

Robert Yee, Department of History, Princeton University, I29 Dickinson Hall, Princeton, NJ 08544, USA; email: ryee@princeton.edu. I am grateful to Professor Harold James, Julia Marino, the two anonymous referees of this journal, and editor Stefano Battilossi for all their helpful comments. I would also like to thank Sarah Patton at the Hoover Institution, Stanford University, and the archivists and staff at the Seeley G. Mudd Manuscript Library, Princeton University. All remaining errors are my own. 
restoring macroeconomic order to the economies of the United States and Europe became all the more necessary. In these circumstances, the Dawes Committee emerged at the forefront of European negotiations surrounding the question of reparations.

The legal rationale for the Dawes Plan derived from the Treaty of Versailles' War Guilt Clause, which placed responsibility for the war on the shoulders of Germany and its allies. Debates over reparations remained one of the main points of contention in the interwar period. For contemporaries like Gilbert, reparations centred on the question of how much compensation Germany should and could have paid. John Maynard Keynes argued that the Council of Four's assignment of blame to Germany threatened the 'future life of Europe', especially pertaining 'to frontiers and nationalities, to the balance of power, to imperial aggrandisements, to the future enfeeblement of a strong and dangerous enemy, to revenge and to the shifting by the victors of their unbearable financial burdens on to the shoulders of the defeated' (I920, p. I). Uncertainty over reparations directly fuelled concerns about budgetary imbalances and ensuing cyclical sovereign-debt crises.

The historiography on reparations has often looked at 1924 through the lens of international relations and diplomacy. Denise Artaud described how geopolitical objectives dictated the nature of reparations for Inter-Allied debts. The US government willingly chose to delay the reparations question. Rather than forcing Germany to liquidate its assets abroad immediately, the US sought more moderate demands than their European counterparts (namely Britain and France) in order to reintegrate Germany on an equal footing with its neighbours and achieve a European balance of power (Artaud I979, pp. 364, 376). Similar histories have placed war debts and reparations at the centre of diplomatic concerns (Costigliola I977, p. 9I I; Péteri I992, p. 257). More recent literature on reparations has shifted towards the economic consequences of transfers (Feldman 2005, p. 489; Müller and Busch 2005, p. 286; Ritschl 20I2, p. 944). For Piet Clement, the Transfer Crisis following the Dawes and Young Plans contributed to the Nazi seizure of power in 1933 because they 'failed to take the political sting out of the reparations question' and 'proved unrealistic' given the economic downturn of I929 (Clement 2004, pp. 35-6). Additionally, the timely payment of reparations implied a 'perpetual outflow of capital from Germany', which became increasingly difficult throughout the I920s (James I986, p. 58; Schuker I988, p. 2). The psychological impact of reparations, according to Peter Krüger and Gerald Feldman, represented a financially unrealistic circumstance and culminated in the political instability of the I930s (Krüger I98I, pp. 37-8; Feldman I997, pp. $854-5)$.

Much of the current literature has thus focused on the macroeconomic effects of the Dawes Plan from the point of view of Allied governments; the diplomacy of central banking and financial reform from the point of view of central banks; and the budgetary reforms from the point of view of the German government. For other scholars, both in the I920s and today, the Plan's shortcoming was its 
temporary nature, as it failed to address many pervasive issues (Schuker I976, p. I74; Orde I990, p. 250). This article revisits the question of reparations through the lens not of governments or of central bankers (Schotz I987, pp. I03-IO), but rather of its creators.

The practice of international economic advising had origins in eighteenthcentury Latin America. By the mid I920s, it became 'a fully recognized professional activity' that involved providing expert advice to governments and institutions (Flandreau 2003, pp. I-2). In the case of Germany, corporate agreements sought to address territorial disputes. The Wiesbaden Agreement (I92I) attempted to establish joint-venture schemes whereby French companies could have acquired German ones, effectively turning reparations into a private matter (Maier I975, p. 389; Fischer 2017, p. I9). The later Stinnes-Lubersac Agreement (I922) briefly revisited this issue by coordinating the distribution of German goods that could have been credited to the reparations bill (Bariéty I998, pp. 40-2; Wright 2002, p. I96; Fischer 2005 , p. 443). What made the I924 case different was its focus on currency and central banking. For the committee and its advisers, reform of the German financial system - the creation of a Transfer Office and an independent central bank - comprised the necessary components of economic stabilisation. Furthermore, as others have rightly asserted, the reparations debate directly shaped the political balance of power in interwar Europe (Trachtenberg I980, pp. 66-8; Schuker I976, pp. 6-10).

According to Schuker, the Dawes Plan and the subsequent London Conference brought about a 'new political configuration' in Europe, alleviating the 'poisoned relations between France and Germany' (Schuker I976, p. I79). The economic advisers of the committee were an integral, if not leading, component of this process. They worked alongside the delegates to bring about a reconfiguration of German banking under foreign oversight. How did the Dawes Committee and its advisers confront the question of war reparations given the uncertainty of Germany's ability to pay? In what ways did their findings address what appeared to be an unsolvable fiscal problem? Using internal reports and memoranda, this research explores the various plans and proposals crafted by the advisers: Edwin W. Kemmerer, a Princeton economist; Arthur N. Young, an economist at the State Department who had been a student of Kemmerer's; Alan Gustavus Goldsmith from the Department of Commerce; and Joseph S. Davis, a Stanford economist. The Plan, although only nominally an interim measure, served a pivotal role in reforming and restructuring the banking system. Kemmerer and Young, in particular, saw the necessity of resolving the Ruhr crisis as a prerequisite for the long-term question of reparations. Although the Committee only claimed to be interested in the fiscal terms of reparations, they also worked to address the geopolitical tension between France and Germany. The Plan itself, in its emphasis on economic stability, was faced with a political dilemma, exploring the question of military occupation via the question of reparations. 


\section{I}

Germany and the Allied governments had borrowed heavily during World War I and, as a result, suffered from unbalanced budgets and currency crises in its aftermath. The rise in public-sector debt, for instance, affected the issuance of new shares on the stock market, which was a key determinant in market expectations (James I992, p. 609). For the French, reparations offered a potential solution to their economic woes (Trachtenberg I979, pp. 25-6; Schwabe I979, p. 68). In its early stages, the provisional bill, including periodic cash payments, deliveries in kind and credits, for Germany alone was set at 20 billion gold marks (GM) (Marks I978, pp. 233-4). For some, like Minister of Finance Louis-Lucien Klotz, the urgency of resolving the reparations debate meant that Germany needed to pay: 'L'Allemagne paiera' (Sauvy I984, p. 24). And, for economists like Davis, currency expansion during the war had contributed to the uncertainty over postwar currency regimes and price levels (Davis I920, p. 8).

After international conferences in Bologna, Spa and Paris, the Inter-Allied Reparations Commission set the new liability for the Central Powers to I 32 billion GM, or around 33 billion US dollars (USD), dictated by the terms of the London Schedule of Payments on 5 May I92 I (Marks I969, pp. 358-63). The total amount, overseen by the Comité des Garanties, included three bonds: Series A (I 2 billion GM for war damages), Series B (38 billion for Inter-Allied debts) and Series C (82 billion, contingent on Germany's hypothetical economic recovery). ${ }^{1}$ The $\mathrm{C}$ bonds were non-interest bearing until the $\mathrm{A}$ and $\mathrm{B}$ bonds had been paid, so the more realistic reparation bill was 50 billion GM (Feldman I997, p. 339).

Some scholars have challenged the notion that these amounts proved debilitating for reconstruction. Sally Marks noted that these series of bonds were 'entirely unreal' and mainly served to 'mislead public opinion in the receiver countries into believing that the I32-billion figure was being maintained' (Marks I978, p. 237). It was indeed uncertain, particularly after the 1922 Genoa Conference, as to how much the Germans were willing and able to pay because they had not engaged in any serious effort to calculate this amount (Trachtenberg I980, p. 68). Relevant to this study, however, is not the possibility or probability of reparation payments, but rather the extent to which the Allied delegates used financial reforms to procure these funds.

Among contemporary onlookers, the reparations question fuelled the very uncertainty that it sought to avoid. Davis later described the 'vicious circle' that had plagued the German economy:

Fear of fresh inflation lowers the international exchange value of the mark, which in turn increases the burden of Germany's reparation payments and brings about enlarged borrowings from the Reichsbank with the effect of expanding the currency, while at the same time it

1 'No. I46: État des Payements' (5 May I92 I), in Calmette I924, pp. 488-9. 
stimulates speculation with the result of reducing the public's share of the treasury bills and further increasing the pressure upon the Reichsbank for currency expansion. (I92 I, p. 3 I3)

By late I922, Germany defaulted on its payments outlined by the London Schedule, the so-called 'second Versailles' (Feldman I997, p. 340). Because the Reichsbank needed to print more reichsmarks to meet the terms of the repayment scheme, investors' confidence and fears of inflation created a self-fulfilling prophecy. In the summer of the following year, monthly inflation rose to more than ioo per cent (Eichengreen I992, p. I25). Reparations represented both an impediment to political stability and a hindrance to economic growth, the constraints of which necessitated a more stable schedule of repayments (Holtfrerich I980, pp. I 52-4; Balderston 2002, pp. 34-4I; Sargent 20I3, pp. 60-2).

When the Reparations Commission announced the default, France and Belgium began discussions on economic sanctions, later imposing a coal blockade between occupied and unoccupied Germany (Trachtenberg I980, pp. 293-8). At first, French policy, however unplanned it seemed to be, focused on compensation for Germany's continual default on payments in kind, such as coal and timber. The occupation was certainly an economic response to defaults on reparation payments, but it was also a political statement, putting pressure on Germany to adhere to the Paris peace agreements (Jeannesson I998, pp. 72-3). Because the Treaty of Versailles did not provide a lasting solution to questions of reparations and of security, the French government strived to use economic means for political ends (Jeannesson I996, p. 57).

Hardships brought about by the occupation exacerbated the reparations problem. According to the Reich Statistical Office, the Ruhr crisis resulted in Germany's diminished capacity to pay reparations (Feldman I997, p. 670). High unemployment came at a social cost, provoking social unrest among communists in the Ruhr and Hitler's Beer Hall Putsch in Munich (Ritschl I999, p. I38). These pressures expedited Anglo-American attempts to facilitate reparations. According to O'Riordan, the British 'reaffirmed their friendship with France, while at the same time calling for a French initiative to end the crisis' (O'Riordan 200I, pp. I25-6). Meanwhile, Secretary of the Treasury Andrew Mellon, along with President Herbert Hoover, noted that the consequences of a financially unstable Europe could have had transatlantic repercussions (Wueschner I999, p. 25).

On 30 November I923, the Allied Reparations Commission approved the establishment of the Dawes Committee, which was tasked with balancing the German budget and identifying a new plan for repayment. The committee considered budgetary and monetary reform in order to resolve the reparations dispute between France and Germany. ${ }^{2}$ The British Foreign Office played a diplomatic role in persuading the other Allied countries, namely France, to join the Dawes Committee (O'Riordan

2 Edwin W. Kemmerer Papers (MCi 46), Department of Rare Books and Special Collections, Princeton University [henceforth EKP], 'Address by General Charles G. Dawes, American Member and President of the First Committee of Experts of the Reparations Commission, at the opening session 
200 I, pp. I34-6). Convincing Prime Minister Raymond Poincaré to accept an international, impartial body to assess Germany's willingness to pay required a second group, the McKenna Committee, to resolve the problem of capital repatriation. It was indeed, as Schuker noted 'little more than a sop to public opinion', while Charles Kindleberger found that it was 'of no importance save for French amour propre' (Kindleberger I973, p. 21; Schuker I976, p. I 8I). Yet allowing the reparations question to be answered by economists, rather than politicians, was itself a sign of defeated French geopolitical dominance (Schuker I976, p. 384; Schotz I987, p. I22).

For the Dawes Committee, each of the Allied countries dispatched a delegation of government experts to London. The Americans sent Charles G. Dawes, the former Comptroller of the Currency and Director of the Bureau of the Budget, who had close ties with the French. Also in attendance was Owen D. Young, founder of the Radio Corporation of America, who handled day-to-day negotiations and maintained relations with the German delegation. ${ }^{3}$ In their nominations, the State Department wanted to avoid placing Wall Street bankers on the committee for 'visual reasons' (Link I970, p. 215). For additional support, the committee engaged two economists, Edwin Kemmerer and Arthur Young. Other representatives included Émile Francqui, a prominent Belgian banker; Josiah Stamp and Robert Kindersley, directors at the Bank of England; Jean Parmentier, the French Inspector General of Finance; and Alberto Pirelli, an Italian industrialist.

Between the appointment of the committee in November I923 and the London Conference the following July, how was the financial and geopolitical decision on reparations conceived, written and accepted? What economic rationale did the committee employ to justify the terms of Germany's annual repayments? Based on contemporary economic theories, several advisers aimed to sway committee decisions in an attempt to bring stability to the global financial system. As Roland W. Boyden, an American lawyer and unofficial representative on the Reparations Commission, remarked, the economists and other supporters of the committee played a significant role in negotiations: 'without them no committee of businessmen, however eminent, could have formulated a report worth cable charges across the Atlantic' (I924, p. 583). An analysis of the advisers' correspondence and proposals gives a more holistic picture of the reparations debate.

At the beginning of its first session in London on I 4 January I924, Dawes set the tone: the delegates now were 'confronted with the necessity of finding stable conclusions where no conditions were stable'. ${ }^{4}$ Yet, with the guidance of the committee, he

of the First Committee of Experts', box I64, folder 2, 'Dawes Committee Memoranda - General, I924', 4; Gilbert I926, p. iv.

3 Charles Dawes, '[Diary entry]' (6 Feb. I924), in Dawes I939, p. 76.

4 EKP, 'Address by General Charles G. Dawes', 3. 
emphasised that 'the reestablishment of German productivity is the starting point of European prosperity'. At the same time, he knew that French support was 'key to the situation', and he strived to maintain relations with one of the delegates, Parmentier. ${ }^{6}$ Over the course of the next year, the members of the committee circulated various reports, plans and proposals for the payment of war reparations (Table I).

Stabilising the currency and creating a gold discount bank, despite the risks of fluctuations in the price of gold, were among the committee's priorities (James I985, pp. 27-8). A meeting with Hjalmar Schacht, President of the Reichsbank, on 2 I January laid the groundwork for this banking reform (Schacht I953, pp. 258-60). Schacht had previously overseen the Rentenbank, which pegged the newly created Rentenmark (RM) to an exchange rate of 4.2 RM-USD (Pohl and Schneider I999, p. I 5; Ahamed 2009, p. I 85). Although he viewed the RM as a temporary solution, believing that a country's currency needed to be backed by gold, his monetary plan succeeded in stopping the depreciation of the mark (Sargent 2013, p. 62). As he later described, the ability of the Rentenbank to reject a request for I,200 million Rentenmark from the Ministry of Finance allowed it to assert its independence and bring the country back to a balanced budget (Schacht I927, pp. 86-7).

Following the meeting with Schacht, the committee released its first communiqué, outlining the need for an international bank to stabilise the RM. They were assisted by technical advisers, often university-trained economists whose main role was providing an outside perspective for the proceedings. Edwin Kemmerer, a Princeton economist and financial adviser to foreign governments (or 'money doctor'), spearheaded this initiative and corresponded with each delegate over the course of the next several months (Flandreau 2003; Schuker 2003). In his memoranda, he stressed the need for a single and unified currency in Germany. ${ }^{7}$ A new central bank, one 'independent of government control so far ... as any obligation to lend money is concerned', was essential for reform. ${ }^{8}$ Unlike the Reichsbank, Kemmerer's 'bank of issue' would have operated autonomously 'without regard for the fiscal needs of the government'. ' It aimed to revive the German economy through export-driven trade.

The 'Proposed German Bank' sought to stabilise exchange rates by purchasing foreign bills and gold. It also acted as a depository for funds later paid to the Reparations Commission via the Transfer Office. ${ }^{10}$ Kemmerer envisioned a board

5 Ibid., 4.

6 Charles Dawes, '[Diary entry]', (Io Jan. I924), in Dawes I939, p. I3.

7 Benjamin Strong Collection (MCI 28 ), Department of Rare Books and Special Collections, Princeton University [henceforth BSC], E. W. Kemmerer, 'The desirability of a unified currency in Germany' (22 Jan. I924), box 3, folder I, 'Edwin Kemmerer Memoranda', I.

8 BSC, E. W. Kemmerer, 'Can stability of a currency be attained and retained without a balanced budget?' (22 Jan. I924), box 3, folder I, 'Edwin Kemmerer Memoranda', 2.

9 Ibid., 3-4.

10 BSC, Kemmerer, 'Outline of plan for proposed German Bank', I-2. 
Table I. Members of the Dawes Committee and its economic advisers

\begin{tabular}{|c|c|c|}
\hline Country & Delegate & Occupation and experience \\
\hline Belgium & Maurice Houtart & $\begin{array}{l}\text { Member of Chamber of Representatives; Director of } \\
\text { the Banque de Bruxelles }\end{array}$ \\
\hline Belgium & Émile Francqui & $\begin{array}{l}\text { Director of Société Générale de Belgique; former } \\
\text { Belgian Consul in Imperial China; Minister of State }\end{array}$ \\
\hline Britain & Josiah Stamp & $\begin{array}{l}\text { Director of the Bank of England; Chairman of the } \\
\text { London, Midland and Scottish Railway }\end{array}$ \\
\hline Britain & $\begin{array}{l}\text { Robert } \\
\text { Kindersley }\end{array}$ & $\begin{array}{l}\text { Director of the Bank of England; Governor of the } \\
\text { Hudson's Bay Company; Partner and Chairman at } \\
\text { Lazard Frères \& Co. }\end{array}$ \\
\hline France & Jean Parmentier & $\begin{array}{l}\text { Inspector General of Finance; Director of the General } \\
\text { Movement of Funds in the Treasury }\end{array}$ \\
\hline France & Edgard Allix & $\begin{array}{l}\text { Professor of Law at the École des Hautes Études } \\
\text { Commerciales (HEC) de Paris }\end{array}$ \\
\hline Italy & Alberto Pirelli & $\begin{array}{l}\text { Delegate to the International Labour Office of } \\
\text { Geneva; Member of the League of Nations } \\
\text { Economic Committee }\end{array}$ \\
\hline Italy & Federico Flora & $\begin{array}{l}\text { Professor of Finance at the University of Bologna; } \\
\text { Director of Ferrovie dello Stato Italiane (Italian State } \\
\text { Railways) }\end{array}$ \\
\hline US & Charles Dawes & $\begin{array}{l}\text { Director of the Bureau of the Budget; Comptroller of } \\
\text { the Currency }\end{array}$ \\
\hline US & Owen Young & $\begin{array}{l}\text { Chairman and President of General Electric; } \\
\text { Chairman of the Radio Corporation of America }\end{array}$ \\
\hline \multicolumn{3}{|c|}{ Economic advisers } \\
\hline US & $\begin{array}{l}\text { Edwin Walter } \\
\text { Kemmerer }\end{array}$ & $\begin{array}{l}\text { Professor of Economics and Finance, Princeton } \\
\text { University } \\
\text { Education: Wesleyan University (BA, I } 899) \text { and } \\
\text { Cornell University (PhD, I903) }\end{array}$ \\
\hline US & $\begin{array}{l}\text { Arthur Nichols } \\
\text { Young }\end{array}$ & $\begin{array}{l}\text { Economic adviser, Department of State; former } \\
\text { Instructor of Economics, Princeton University } \\
\text { Education: Occidental College (BA, I9Io), (LLD, } \\
\text { I937); Princeton University (MA, I9I I), (PhD, } \\
\text { I9I4); George Washington University (LLB, I927) }\end{array}$ \\
\hline US & $\begin{array}{l}\text { Alan Gustavus } \\
\text { Goldsmith }\end{array}$ & $\begin{array}{l}\text { Chief of the European Division, Department of } \\
\text { Commerce } \\
\text { Education: Kenyon College (BS, I9I I) }\end{array}$ \\
\hline US & $\begin{array}{l}\text { Joseph Stancliffe } \\
\text { Davis }\end{array}$ & $\begin{array}{l}\text { Professor of Economics, Stanford University } \\
\text { Education: Harvard University (BA, I908), } \\
\text { (PhD, I9I3) }\end{array}$ \\
\hline
\end{tabular}


of directors comprised of both German nationals and representatives from the central banks of Belgium, Britain, France, Italy and the US. ${ }^{11}$ Moreover, there needed to be a clear distinction between the issue department and the department for banking operations, a separation that was enshrined in the Bank of England's Charter Act 80 years prior. While the former printed notes under direction of a comptroller, the latter dealt with the revenues and expenditures of the German government in a manner similar to the Ministry of Finance. For the advisers, it was vital to distance the operations of the central bank from those of the government. This legal separation, coupled with strict adherence to the gold standard, would have allowed the currency to meet the most pressing needs of the Germany economy (James I987, p. 7I). One adviser, Alan Goldsmith, head of the European Division in the US Department of Commerce, even suggested giving complete bank oversight to a single controller (Schotz I987, p. I37). Such efforts to reform central banking sought to avoid the dreaded budget deficits. ${ }^{12}$

The Belgian administration concerned itself with these budget deficits along with the long-term impact on public debts. Drawing from the budgetary documents from each of the major European powers, Maurice Frère, a Belgian civil servant and adviser to the committee, estimated Germany's national debt to be approximately 2.26 trillion GM in I923 ${ }^{13}$ This seemingly unsustainable amount alarmed the committee, especially Maurice Houtart, director of the private Banque de Bruxelles, who noted that the post-I924 German budget made 'no provisions for reparation'. ${ }^{14}$ Only with future decreases in public expenditures - military pensions (8 I o million GM), unemployment insurance (800 million) and 'social expenditure' (360 million) - would the Germans have begun a path towards reform. An estimated savings of nearly 2 billion GM, coupled with additional revenue from income tax (Einkommensteuer), corporation tax (Körperschaftsteuer) and wealth tax (Vermögensteuer), he surmised, could have led to a budget surplus of $\mathrm{I} .5$ billion GM. ${ }^{15}$

Compromise was certainly possible, particularly with the British delegation in attendance. Both the German and British administrations desired a reformed central bank for Germany, the starting capital for which the Bank of England advanced (Schotz I987, pp. I33-4). Yet, while Houtart proposed a German budget divided between reparations and internal expenditures, as Goldsmith

11 BSC, E. W. Kemmerer, '[Rough draft of] Suggestions as basis for discussion concerning the control of the proposed new bank' (30 Jan. I924), box 3, folder I, 'Edwin Kemmerer Memoranda', I-2.

12 EKP, 'Memorandum for Mr. Dawes: principal features of plan for new Bank of Issue' (I I Feb. I924), box I64, folder 9, 'Dawes Committee Memoranda - Dawes Committee Papers, I924', 6-7.

13 BSC, Maurice Frère, 'Comparison of the public debts of Germany, Belgium, France, Great Britain and Italy' (25 Jan. I924), box 4, folder I 5 , 'Capacity to Pay', I.

14 BSC, Maurice Houtart, 'Elasticity of the German budget' (7 Feb. I924), box 4, folder I 5, 'Capacity to pay', I.

15 Ibid., 2-3. 
observed, the British delegate, Robert Kindersley, pushed for a centralised budget for simplicity. ${ }^{16}$ The shared sentiment among many members of the committee was also the desire to reform the railway system and strive to achieve a budget surplus in the following fiscal year (Depoortere I997, pp. 283-6).

\section{I I}

At the end of January I924, the committee travelled to Berlin where Gustav Stresemann, the German Minister of Foreign Affairs, took great interest in the advisers' duties. He wanted to procure a line of credit aimed at rebuilding domestic infrastructure and restoring economic and political sovereignty through Gleichberechtigung (Wright 2002, p. 284; Fischer 20I7, p. 21). ${ }^{17}$ The German administration as a whole also appeared willing to help the advisers. For instance, it ordered the publication of Material for a Study of Germany's Economy, Currency and Finance to demonstrate its financial limits. Their 'Analysis of Revenues from Taxation, I920-I923' showed the historic decrease in government revenue from taxation and export duties, dropping from 3,2 I 8.4 to 9I2.5 million GM over a four-year time period. ${ }^{18}$ After the period of Weimar hyperinflation, a change in the national character of taxes was precipitated (Feldman I997, p. 580). The report's preface acknowledged that the current economic situation was 'dominated by the occupation of the Rhine and Ruhr districts ... [which] have been economically separated from the rest of the Reich'. ${ }^{19}$ Stresemann in particular was careful in convincing the foreign delegates that Germany needed reform and economic unity, but not to the extent that it would threaten the geopolitical interests of France (Link I970, p. 22I). But, for them, any such return to a financially stable Germany was contingent on the withdrawal of troops.

When Émile Francqui, a Belgian banker, presented his findings on 6 February to the Reparations Commission, it became clear that the Belgians were more willing than the French to compromise. As a former consul in Imperial China, Francqui had led negotiations surrounding the building of the Hankow-Canton railroad in I90 I and, for this reason, focused mainly on mortgages on railways and tax increases (Depoortere 1997, p. 33I). ${ }^{20}$ According to his report, the German government needed to claim a 'portion of the large profits' from the railroads and manufacturers

16 Alan Gustavus Goldsmith Letters (24002), Hoover Institution Archives, Stanford University [henceforth AGL], '[Letter to Chris A. Herter]' (20 Jan. I924), folder I, 'Committee of Experts of the Reparations Commission', 3 .

17 AYP, Arthur Young, '[Diary entry]' (2 Feb. I924), box I, folder I, 'Reparations and the Reparations Commission, i9 18-I934', I.

18 EKP, 'Material for a study of Germany's economy, currency and finance, by order of the German government', box I64, folder I, 'Currency, I924-I926', 33.

19 Ibid., I.

20 Charles Dawes, '[Diary entry]' (I5 Jan. I924), in Dawes I939, p. 20. 
in return for the cancellation of their state debts. ${ }^{21} \mathrm{He}$ even sought to grant the Germans a degree of autonomy, as the creditors merely set the reparation requirements, while the debtor was left to 'determine the methods of raising it'. ${ }^{22}$ Although the British Foreign Office hesitated in sanctioning Franco-Belgian control of railways, which appeared to be a means for maintaining significant longterm power over Germany, Francqui's proposals influenced the advisers' views on railway reform (O’Riordan 200 I, p. I 53).

Whereas Kemmerer concerned himself with currency and Francqui with railways, Josiah Stamp from the British delegation addressed budgetary reform in his reports. As a director of the Bank of England, Stamp strongly favoured a balanced budget, one that led to a 'restoration of a prosperous internal economy' while also fulfilling the terms of the reparations agreement. ${ }^{23} \mathrm{He}$ was particularly enamored by the idea that budget deficits destabilised the financial system. As a result, he had continually 'been working night and day on the German budget', according to Arthur Young's diary. ${ }^{24}$ The collection of taxes appeared throughout his copious notes and memoranda, wherein he described the failures of the German government throughout the years of Weimar hyperinflation.

For some, successful currency reform could only have been achieved after balancing the budget. Dawes, as he explained in his opening speech to the committee, believed that ' $[t]$ he first step is ... to devise a system for stabilising Germany's currency, so that we can get some water to run through the budget-mill. Let us build the mill after we find the stream to turn its wheels. ${ }^{, 2}$ In contrast, Stamp had doubts that the committee would have been able to achieve successful budgetary reforms because of the nature of taxes: 'Before such an administration can work effectively, the necessary time must elapse until the assessing authority can assess to income tax the revenues earned ... a full year at least must pass. ${ }^{26}$ Because direct taxation was a lagging indicator, he predicted measurement difficulties for the committee going forward.

Along with Joseph Davis, Kemmerer countered this claim by turning to the case of Austria. The Austrian government was able to 'borrow abroad or internally, enough to meet its deficits' and, indeed, 'budget deficits can be financed without currency inflation'. ${ }^{27}$ The stabilisation of the Austrian schilling did not occur through currency reform, but rather through a commitment of the government to adopt a fiscal policy

21 BSC, Émile Francqui, 'Report by M. Francqui' (6 Feb. I924), box 4, folder I5, 'Capacity to Pay', 4.

22 Charles Dawes, '[Diary entry]' (8 Feb. I924), in Dawes I939, p. 8I.

23 BSC, Sir Josiah Stamp, 'How soon can the budget position respond to currency stabilisation?' (I I Feb. I924), box 4, folder I5, 'Capacity to Pay', I.

24 AYP, Arthur Young, '[Diary entry]' (s Feb. I924), box I, folder I, 'Reparations and the Reparations Commission, I918-I934', I.

25 EKP, 'Address by General Charles G. Dawes', 5 .

26 BSC, Stamp, 'How soon can the budget position respond to currency stabilisation?', 5 .

27 BSC, E. W. Kemmerer and J. S. Davis, 'Is a balanced budget necessary for currency stability?' (25 Jan. I924), box 3, folder I, 'Edwin Kemmerer Memoranda', 2. 
Table 2. The balance sheet of Kemmerer's first proposed bank of issue

\begin{tabular}{llll}
\hline \hline Assets & Liabilities & \\
\hline $\begin{array}{l}\text { Gold and its equivalent } \\
\text { in foreign currencies } \\
\text { Mortgage assets }\end{array}$ & 400,000,000 GM & Capital from shares sold & $400,000,000 \mathrm{GM}$ \\
Rentenbank loans & $2,400,000,000$ & $\begin{array}{c}\text { Deferred shares given } \\
\text { to mortgagors } \\
\text { Rentenbank notes } \\
\text { outstanding }\end{array}$ & $2,400,000,000$ \\
$\begin{array}{l}\text { Gold from Reichsbank } \\
\text { Commercial bills } \\
\text { endorsed by Reichsbank }\end{array}$ & $\begin{array}{c}400,000,000 \\
\text { I00,000,000 }\end{array}$ & $\begin{array}{c}2,400,000,000 \\
500,000,000\end{array}$ & \\
\hline \hline
\end{tabular}

Source: BSC, E. W. Kemmerer, 'Tentative balance sheet of proposed new bank at time of opening for business' (30 Jan. I924), box 3, folder I, 'Edwin Kemmerer Memoranda', I.

in line with its USD peg (Sargent 20I3, pp. 52-3). Using this case study, Kemmerer framed similar reforms of the German banking institution with starting capital of nearly 6 billion GM (Table 2$){ }^{28}$

In opposition to Stamp, Kemmerer pushed for the creation of a new bank of issue, coining it the 'Bank of Germany'. ${ }^{29}$ He suggested a starting 'paid-up capital' (i.e. paid-in capital) of 400 million GM, which was later increased to 600 million GM. ${ }^{30}$ By denominating the bank's assets in GM, rather than RM, the bank of issue could have protected the RM from both potential devaluations and speculative attacks. Dawes also saw the bank serving as a guarantor of reparations commensurate with taxation, an idea proposed by Kemmerer in his memorandum from a few weeks prior. ${ }^{31}$ Although it was based in Germany, the proposed bank would have operated under strict international oversight and the administration of 12 members, half of whom were to be German nationals and the other half Allied representatives.

In some ways, the American experts were more motivated than their German delegation to seek economic recovery so as to ensure the payment of reparations. A

${ }^{28}$ BSC, E. W. Kemmerer, 'Outline of plan for proposed German Bank, prepared to suggest a positive form: topics for discussion' (26 Jan. I924), box 3, folder I, 'Edwin Kemmerer Memoranda', I.

29 EKP, 'Memorandum for Mr. Dawes: plan for the new gold Bank of Issue in Germany' (20 Feb. I924), box I64, folder 9, 'Dawes Committee Memoranda - Dawes Committee Papers, I924', I; Charles Dawes, '[Communiqué]' (23 Jan. I924), in Dawes I939, p. 53.

30 The Dawes Plan set the starting capital at 400 million GM; EKP, 'Memorandum for Mr. Dawes: plan for the new gold Bank of Issue in Germany', 3; AGL, '[Letter to Chris A. Herter]' (24 Feb. 1924), folder I, 'Committee of Experts of the Reparations Commission', I.

31 Charles Dawes, 'Synopsis' (I I Feb. 1924), in Dawes 1939, pp. 97-8; Edwin Kemmerer, 'Memorandum for Mr. Dawes: a possible alternative plan for reparation' (9 Feb. I924), in Dawes I939, pp. 88-9. 
financially sound Germany would have expedited the repayment of Inter-Allied war debts to the US. While Dawes stressed that the committee did not intend to make any recommendations on the Ruhr occupation, the advisers recognised that few reforms could have been implemented while military conflict was still ongoing. Goldsmith, in particular, expressed concern over the 'unsettled question' of how to continue the occupation 'without in any way interfering with Germany's economic unity, and hence her productivity'. ${ }^{32}$ For economists like Goldsmith and even Francqui, liberating the industrial core of Germany was vital to successful financial reforms.

One issue that pervaded committee discussions was whether to place the German bank of issue on the gold standard. Kemmerer justified his proposal for a strict gold standard with the desire to maintain monetary stability. Pegging the currency to gold could have prevented fluctuations in the real value of payments. But Dawes hesitated to authorise a gold standard in Germany while 'her neighboring competitors are still struggling with unstabilized currencies'. ${ }^{33}$ Adviser Arthur Young seemed particularly uncertain as to how to assuage the demands of the French and Belgians: they 'attacked the gold standard feature and said it should not be in the plan, since "Germany would not then enjoy a unique and privileged position in Europe in this respect", 34 Even Montagu Norman, Governor of the Bank of England, opposed the gold standard, fearing it would have been too limiting. ${ }^{35}$ The prospect of a rival dollar-based, not sterling-based, gold bloc characterised many of these financial advisory missions (Rosenberg I985, pp. I99-20I).

By I 3 March, the French government procured a loan of Ioo million USD from the American firm J. P. Morgan to protect its gold reserves. Dawes and Young had met with officials from J. P. Morgan two days before to secure a loan that would have created a 'financial incentive' for the French to support stabilising Germany (Dunlap 2016, pp. I72-3). Contingent on tax reform and a cut in public expenditures, the Morgan loan aimed to bring about economic stability (Maier I975, p. 46I; Schuker I976, p. I08). Only then would the French have accepted any kind of international agreement, as they desired an economic reason to withdraw from the Ruhr (Costigliola I976, p. 489). Similarly, the Belgian administration conceded that they would have preferred solid guarantees of payments in exchange for a reduction in the total amount (Depoortere I997, p. 293).

On the German side, the incentives for supporting international oversight derived mainly from the possibility of settling both the reparations and the Ruhr debates (Link I970, p. 275). Restructuring of domestic public finance appeared to be requirement for the foreign credits and the potential evacuation of the Ruhr. Stresemann, who fully backed the plan, assured Young that the former's administration largely agreed

32 AGL, '[Letter to Chris A. Herter]' (24 Feb. I924), 2.

33 Charles Dawes, '[Diary entry]', (I4 Mar. I924) in Dawes I939, p. I63.

34 AYP, Arthur Young, '[Diary entry]' (I 2 Mar. I924), box I, folder I, 'Reparations and the Reparations Commission, I918-I934', 2.

35 Ibid., 3. 
with it, but he could not speak on behalf of the German industrialists, many of whom objected to the sale of industrial territories in the Ruhr to the French (Costigliola I976, p. 490). Several of Germany's leading industrialists, including Hugo Stinnes and Fritz Thyssen, pushed for closer cooperation and even a potential merger with French businesses (Fischer 2005, pp. 46I-2). Yet the participation of the US was perhaps most vital to the plan's acceptance, as the German administration believed that a rejection of the plan would have granted France the freedom to prolong the occupation (Wright 2002, pp. 272-3).

The Belgians 'with great reluctance ... joined the French in the Ruhr venture' and only in pursuit of a 'restoration of the solid Anglo-French entente essential to its security' (Schuker I976, p. I89). Prime Minister Georges Theunis believed that a financial negotiation was preferable to military intervention, whereas Francqui preferred a partial and provisional solution to no solution (Depoortere I997, p. 285). It was, indeed, the French who led the Régie des Chemins de Fer des Territoires Occupés, an initiative to expand further into the Ruhr (Mierzejewski I999, p. 6I). The organisation, headquartered in Düsseldorf, was merely a political instrument, creating a visible mark on the Allied (namely, French) presence in the region (Jeannesson I998, p. I98). In response, Goldsmith, like Francqui two months earlier, pushed for a new railroad plan that may have appeased the French: Germany's railroads were to be privatised, and bonds totaling I I billion GM were to be issued. ${ }^{36} \mathrm{He}$ also hoped the capitalisation of railroads could have persuaded the French to cease their proposals for 'splitting up ... the roads into several systems with emphasis on the Rhine-Ruhr'. ${ }^{37}$

Additional attempts to create Kemmerer's bank of issue coincided with Schacht's attempts to create one as well. In late March, the Reichstag approved of the creation of a German Gold Discount Bank (Deutsche Golddiskontbank), established under the direction of the Reichsbank with private capital (Schacht I927, p. I I I). The bank retained the prerogative to issue notes so long as it could cover at least 50 per cent with gold or short-term foreign bills. ${ }^{38}$ Although Schacht himself nominally established the bank, it is likely that Kemmerer's proposals had some influence on its structure. This assertion is evident from Dawes' diary entry wherein he remarked that Schacht 'asked to be allowed to start a gold bank of issue, something upon which our Committee had already come to a practical understanding' (Schacht I953, p. 228). ${ }^{39}$ Schacht also later reflected on the fact that the Golddiskontbank was the only Notenbank in Europe subject to foreign influence ('eine ausländische Einwirkung') on its board (I927, pp. I25-6).

36 Only 500 million of these bonds were planned to be retained by the government; AGL, '[Letter to Chris A. Herter]' (I7 Mar. I924), folder I, 'Committee of Experts of the Reparations Commission', 2. 37 Ibid.

38 Register of the Arthur N. Young Papers (66005), Hoover Institution Archives, Stanford University [henceforth AYP], 'The Golddiskontbank' (29 Mar. I924), box 3, folder 5, 'German currency and banking, I923-I924', 2.

39 Charles Dawes, '[Diary entry]' (2 I Jan. I924), in Dawes I939, pp. 5I-2. 
The purpose of the Golddiskontbank was to raise domestic capital that the Transfer Office used to pay German creditors (Orde I990, p. 250). Its capital stock was denoted in British pounds sterling, not in dollars or Reichsmarks, because many of the experts felt pounds would have been more suitable for German economic recovery. Governor Norman, of course, favoured this measure, as it provided an opportunity for London to reclaim its position as the financial centre of Europe (Link I970, p. 230; Schotz I987, p. I34). The Bank of England had a long-standing policy of establishing and supporting financial stabilisation programmes abroad, such as in Austria and Hungary (Péteri I992, pp. 240-I; Clarke I967, p. 62). Norman further pushed to increase the credit volume of the Golddiskontbank from 300 to 500 million (Schotz I987, p. I 56). In turn, Schacht welcomed this cooperation with the Bank of England, finding it to be a means of attracting foreign capital to rebuild domestic industry. ${ }^{40}$ Subscribed and managed by the Reichsbank, the sterling-denominated capital of the Golddiskontbank mainly aimed to finance foreign trade (Clarke I967, p. 58). At the same time, article 6 of the charter stipulated that the Golddiskontbank was prohibited from extending loans ('accord credits of any kind') to the German Ministry of Finance or any state governments, thus granting it a degree of independence. ${ }^{41}$

Some hesitated to support these provisions. Because accounts were denominated in pounds sterling and not dollars, Arthur Young now described the newly created Golddiskontbank as effectively 'a sterling bank' (Schotz I987, p. I 47). But the solution to the currency problem did thwart French attempts to divide Germany, while also strengthening the British pound (James I987, pp. 68-9). An initial stock of Io million pounds, half of which was issued to the Reichsbank and the remaining to a consortium of German banks, comprised its starting working capital. ${ }^{42}$ Along with the Reichsbank, which issued the legal currency, and the Rentenbank, which stabilised the economy through its own stable currency, and the Golddiskontbank acted as one of the three concurrent German central banks in I924 (Pohl and Schneider I999, pp. I5-I6).

As the committee's proceedings continued, Young noted that the Europeans in general had become increasingly concerned about the logistics of transfers. Rather than leaving it to the bank of issue, some of the advisers surmised that a separate entity - one not subject to domestic or foreign influences - should have been entrusted to handle the transfer of capital to the creditor countries. ${ }^{43}$ Kemmerer soon thereafter completed the full outline of his bank in his April memorandum:

40 BSC, 'The proposal to create a gold credit bank: statements made by Dr. Schacht to the Reichstag Commission' (I 2 Mar. I924), box 4, folder I4, 'Gold Bank', 2.

41 ANY, 'The Golddiskontbank', 3-4.

42 AYP, 'German Gold Discount Bank' (25 Apr. I924), box 3, folder 5, 'German currency and banking, I923-I924', 4.

43 AYP, Arthur Young, '[Diary entry]' (2 Apr. I924), box I, folder I, 'Reparations and the Reparations Commission, I918-I934'. 
three-quarters of its 400 million GM in paid-up capital was to be offered to subscribers, while the remaining quarter was to be held at the Reichsbank. The proposed bank of issue could have "performed an enormous service, not only to Germany, but to the cause of reparations'. 44

To see through its implementation, the advisers recommended having one or two experts from the committee work directly with the President of the Reichsbank. Kemmerer again proposed increasing the members of the general board from the previous I 2 to I 4 . One of the board's members 'of foreign nationality' acted as a commissioner who authorised all deliveries and the custody of notes. ${ }^{45}$ Norman, recognising the value of a closer bond with Germany, worked to undo some of Kemmerer's plans that restricted the bank's autonomy. The clause regarding foreign oversight was later removed from the plan (Schotz I987, p. I42; Feldman I997, p. 832).

Dawes believed that the final report, submitted on April 8, succeeded in laying an overall framework for a stable German economy: 'the recommendations of the Committee must be considered not as inflicting penalties, but as suggesting means for assisting the economic recovery of all the European peoples and the entry upon a new period of happiness and prosperity'. ${ }^{46}$ For some advisers, certain components of the plan, such as the gold-exchange standard, seemed to have been too restrictive. Arthur Young noted that it did not give a 'proper margin of safety' for flexible reparation payments. ${ }^{47}$ Schacht too was particularly critical, citing its main flaw as having failed to reduce the total amount of war reparations (Ahamed 2009, p. 2 I5). There were also attempts to block some of foreign loans through the Beratungsstelle für Auslandskredite as a means of avoiding inflation (James I985, pp. 44-6). Nonetheless, the advisers' reports demonstrated that they aimed to spur an economic transformation in Germany, a transition 'from defeated enemy into a rehabilitated participant in the international order' (Fischer 20I7, p. 2I).

\section{IV}

The Dawes Plan established a Transfer Office, overseen by the Agent General for Reparation Payments S. Parker Gilbert and five additional experts. ${ }^{48}$ Gilbert was responsible for, as the name suggests, the transfer of capital to the Allies while also mitigating any adverse effects on German exchange rates. The office planned to accept German payments denominated in marks and then convert them into the proper foreign currency for payment to the respective creditor governments. This

44 BSC, Kemmerer, 'Can stability of a currency be attained and retained without a balanced budget?', 4.

45 EKP, 'Memorandum for Mr. Dawes: plan for the new gold Bank of Issue in Germany', $5-8$.

46 Charles Dawes, 'My letter as Chairman transmitting report to the Reparation Commission' (9 Apr. I924) in Dawes I939, p. 2 I 4.

47 AYP, Arthur Young, '[Diary entry]' (8 Apr. I924), box I, folder I, 'Reparations and the Reparations Commission, I918-I934'.

48 Owen Young served as the ad interim Agent General prior to Gilbert's appointment; Reparations Commission I924, p. 27. 
conversion aspect meant that the Germans were no longer responsible for foreign remittance. The committee most likely based some of this framework on Keynes' earlier proposal for an international clearing union, a 'bilateral and reciprocal' agreement among governments to redistribute the private funds of its nationals (Keynes I920, pp. 67-8). The Transfer Office, according to Gilbert, thus became 'the guardian of the German exchange' (I950, p. vii).

Some have criticised the plan for being 'deliberately' vague, even characterising it as an unsatisfactory compromise (Link I970, p. 246; Orde I990, p. 250). However, the plan did address the uncertainty besetting the Ruhr. The sources for reparation payments derived from the newly balanced budget, sale of railway bonds and raising of transport taxes and industrial debentures contingent upon a future Franco-Belgian withdrawal. France also accepted it, in part due to British pressure and because there simply was no feasible alternative (Marks 2003, pp. 59-60). And Germany, upon accepting the plan on April i 5 , agreed to follow the new schedule of payments based on an index of domestic prosperity. Such were the conditions essential for the 'new economic peace' between Germany and its creditors: economic readjustments of the plan, safeguards against default and a return to the "normal economic functioning' of Germany (Dawes I924, p. 3).

From I6 July to I6 August I924, the committee convened in what one scholar described as 'the greatest gathering of statesmen since the Paris Peace Conference of I9I9' (Ahamed 2009, p. 208). The London Conference, at the behest of Prime Minister Ramsay MacDonald, hosted delegates from the Allied countries and Germany to see to the implementation of the committee's plan (Depoortere I997, pp. 3 I2-30; Orde I990, pp. 253-65). The goal was to use the Dawes Plan from April of that year as a basis for a stabilisation protocol (Clarke I967, p. 47). According to Le Temps, there was an 'air of reserved trust' among the delegates. ${ }^{49}$ From the German administration came Stresemann, Minister of Finance Hans Luther and Chancellor Wilhelm Marx (Wright 2002, p. 288). The French and Belgian representatives also included high-ranking officials, such as Étienne Clémentel from the French Ministry of Commerce and Baron Moncheur, the former Belgian ambassador to the US.

At the conference, the Ruhr occupation was the chief concern. The American representatives, such as the US ambassador to the UK. Frank Kellogg, pushed for a firm commitment to military evacuation within one year (Link I970, p. 297). Although Stresemann viewed a withdrawal as a means for winning public support for the plan, newly elected Prime Minister Édouard Herriot at first sought to gain something out of the removal of troops from the region (Wright 2002, p. 288). Given the recent depreciation of the franc, the French administration wanted assurance of capital, either from German reparation payments or American bankers (Marks I978, pp. 248-9). In turn, the Germans pushed for a definitive end-date to

\footnotetext{
49 'Le règlement de la paix: conférence interalliée de Londres' (27 Jul. I924), Le Temps.
} 
the occupation, which continued to serve as a symbol of humiliation and financial obedience (Schuker I976, pp. I93 and 269). Herriot later conceded to an evacuation of the Ruhr within a year in return for the sale of $\mathrm{I} .5$ billion GM in railway bonds and the German acceptance of the new reparations schedule (Maier I975, p. 522).

The plan was neither without flaws nor without critics. Ernest Minor Patterson, Professor of Economics at the University of Pennsylvania, recognised the "extremely intricate' nature of such negotiations, yet argued that the problem would reemerge with Germany's economic recovery: 'bargaining power is bound to increase, and she will call for a more moderate settlement' (I924, pp. IO-I4). In addition, an outside group of economists at Amherst College described the fiscal and industrial issues. Of questionability to them was that Germany's supply of gold proved insufficient to meet its own fiscal needs. The US had maintained a large balance of trade in its favour during the war, forcing many European countries to abandon the gold standard and devalue their currencies. In turn, Germany suffered from a dependency on imports, compounded by the fact that 'there was no fresh supply of gold produced within the country'. ${ }^{50}$ An extension of credit from foreign investors, the economists posited, did not address the dilemma, as credits in the form of foreign loans would not have procured a stable annual return unless Germany became 'a stable industrial community'. ${ }^{51}$ For these economists, the plan appeared to act as only a temporary fix to a much greater structural deficiency, namely the dependency on imports.

The committee explicitly stated that it did not intend to address the question of military occupation: ' $[\mathrm{t}]$ he military aspect of this problem is beyond our terms of reference' (Reparations Commission, p. iii). But, by focusing on the economics of reparations, the committee put an end to the occupation debate. Internal divisions among the delegates perhaps contributed to this goal. The French and Belgian delegations preferred reform of the railways; the British delegation pushed for a balanced budget; and the American delegation, including the advisers, found currency stabilisation to be far more vital. Each of these proposals aimed at financial reform, but also included military-specific elements as well: railways provided transportation of goods and labour to the Ruhr, budgetary reforms limited Germany's capacity to raise capital for war expenditures, and currency reform sought to reintegrate the heavy industries of Germany with those of Europe.

According to one member of the French delegation, the conference effectively instituted a 'new reparation régime in conformity with the Dawes Plan' (Parmentier I924, p. 244). The supervision of the Transfer Office, described at the conference as an 'advisory committee', oversaw the reparation payments, which were indispensable for the French and Belgian acceptance of the plan. ${ }^{52}$ In return,

50 EKP, 'The reparations problem and the Dawes Report' (I924), box I65, folder 4, 'Dawes Report', 24.

51 Ibid., 25.

52 Ministère des Affaires Étrangères I924: 'No. 22: Mémorandum de la Délégation française concernant la Répartition des paiements reçus de l’Allemagne depuis le ier janvier I923' (2 Aug. I924), p. 87; 
Table 3. Plan of reparation payments according to the Dawes Committee

\begin{tabular}{ll}
\hline \hline Year & Minimum annual payment (in GM) \\
\hline Ist year [1924] & I,O00 million \\
2nd year [I925] & I,220 million \\
3rd year [1926] & I,200 million \\
4th year [1927] & I,750 million \\
5th year [1928] & 2,500 million \\
\hline \hline
\end{tabular}

Source: Reparations Commission, 'Rapport du premier comité d'experts', 23-4.

the Belgians conceded that the Office needed to remain independent of political influence to avoid any serious possibility of a 'dead lock' in reparation payments. ${ }^{53}$ The conference's major accomplishments included the end to the military occupation in a year and a reduced reparations bill (Marks 2003, p. 6I). As Wright argued, the conference thus embodied 'the moment when Germany again met the Allies on equal terms and began to be treated more as a partner than an ex-enemy' (Wright 2002, p. 290).

The committee used the concept of 'economic peace' to demonstrate how successful reforms in public finance were contingent upon a confirmed end date to the French occupation policy (Besatzungspolitik) (Kleinschmidt 2004, p. I45). According to Schuker, although 'questions of military occupation, or of political guarantees and penalties ... lay outside the committee's jurisdiction', only the end of the 'direct exploitation of productive pledges in the Ruhr' could have facilitated reparations payments (I976, p. I86). Its achievement, in this regard, was its ability to address certain topics without directly spurring Franco-Belgian dissent. For if the committee had simply stated outright what the British or American governments felt, it probably would have been less effective. These measures, coupled with the reduction in the annual reparations rate and the secured line of credit through the external loan, represented the contribution of the committee's advisers.

Within the first year, the German government made a payment of I billion GM (Table 3). Following its first payment, the commission continually reassessed Germany's budget based on exports and imports; budget receipts and expenditures; railroad traffic; consumption of sugar, tobacco, beer and alcohol; census statistics; and consumption of coal per capita. ${ }^{54}$ One estimate placed the total reparations

'No. 40: Arrangement entre la Commission des Réparations et le Gouvernement allemand' (9 Aug. I924), p. II 4.

${ }^{53}$ Ministère des Affaires Étrangères I924: 'Quatrième séance plénière' (2 Aug. I924), p. 38.

54 'Agreement between the Reparation Commission and the German government', American Journal of International Law, I9, no. I (I925), p. 27. 
paid at 20.598 billion GM (Marks I978, p. 233), while another approximated 22.89 billion (Schuker I976, p. I06).

In some instances, scholars have argued that the actual figures were rather moot since many Germans, including Schacht, expressed a clear unwillingness to pay (Mierzejewski I999, p. 84). Furthermore, the German administration sought to cover most of its reparation transfers by borrowing on international markets (Ritschl I999, p. I29). The German government, along with the British Treasury and American bankers, believed that Germany would have never been able to make such payments anyway (McNeil I986, p. 27). The economic advisers, remaining silent on the topic, nonetheless set forth these proposals because it was a means of responding to Franco-German disputes. They would rather have seen an appeased French government and partially paid reparations bill than a debilitated Germany with spillover effects in the world economy. Certainly, as Kemmerer reflected, the opportunity for Germany to meet its reparation payments came from its exports abroad (1925, p. 9). The loan, in its most basic capacity, provided a temporary respite for the Germans to reform public finance.

Throughout 1924, Kemmerer, the committee and the Transfer Office struggled to resolve the problem of transferring capital while simultaneously ensuring stability in both the payer and payee countries. For their plans to be successfully implemented, financial institutions and central banks from the Allied Powers necessarily needed to extend a loan to Germany. The plan's provisions 'would reestablish German economic sovereignty in the Ruhr and Rhineland and would facilitate badly needed credits from abroad' (Maier I975, p. 486). Central to this recovery was the external loan of October I924. As MacDonald outlined in London, the first goal of the conference was German economic and fiscal unity, while the second was the affirmation of a much-needed loan. ${ }^{55}$ A syndicate of international banks jointly issued a loan equivalent to over 800 million GM (or 967 million Reichsmarks) with an annual interest rate of 7.0 per cent. ${ }^{56}$ It provided a line of foreign credit necessary to begin transfer operations, as well as a means for financing the sizable trade deficits (Balderston 2002, p. 24).

While the French depended on the Morgan loan in March for its own economic recovery, the Germans received their share of capital from an international consortium of banks in October 1924. Each of the tranches came from a bank in a sponsoring country, with J. P. Morgan contributing half the total amount (Table 4). At the head of this international effort was Arthur Anderson, a partner at

55 Ministère des Affaires Étrangères I924: 'Première séance plénière' (I6 Jul. I924), p. I I.

56 Ministère des Affaires Étrangères I924: 'No. 37: Résolution au sujet de l'émission de l'emprunt', p. 96. 
Table 4. The structure of the German external loan of 1924

\begin{tabular}{|c|c|c|c|c|}
\hline Tranche & $\operatorname{Bank}(\mathrm{s})$ & Location & $\begin{array}{l}\text { Nominal } \\
\text { amount } \\
\text { (millions) }\end{array}$ & GM \\
\hline American & J. P. Morgan \& Co. & New York & I Iо.o USD & $400,628,338.50$ \\
\hline British & Bank of England & London & I2 GBP & I92,943,009.66 \\
\hline Belgian & $\begin{array}{l}\text { La Société Nationale de } \\
\text { Crédit à l'Industrie }\end{array}$ & Brussels & I.5 GBP & $24,375,656.83$ \\
\hline Dutch & $\begin{array}{l}\text { Hope and Co. and } \\
\text { Nederlandsche Handel- } \\
\text { Maatschappij }\end{array}$ & Amsterdam & $2.5 \mathrm{GBP}$ & $40,642,203 \cdot 74$ \\
\hline French & Lazard Frères \& Cie. & Paris & $3.0 \mathrm{GBP}$ & $48, \mathrm{I} 78,586.86$ \\
\hline Italian & Banca d'Italia & Rome & Ioo ITL & I $5,696,75$ I.68 \\
\hline Swedish & Stockholms Enskilda Bank & Stockholm & 25.2 SEK & $24,250,106.64$ \\
\hline Swiss (sterling) & Crédit Suisse & Zürich & 0.236 GBP & $38,850,540.37$ \\
\hline Swiss (francs) & Crédit Suisse & Zürich & I $5.0 \mathrm{CHF}$ & $9,52 \mathrm{I}, 735.95$ \\
\hline \multirow[t]{4}{*}{ German } & Reichsbank & Berlin & 0.36 GBP & $5,926,353.62$ \\
\hline & & & Subtotal & $8 \mathrm{OI}, \mathrm{OI} 3,283.85$ \\
\hline & & & $\begin{array}{l}\text { Less: Issuing } \\
\text { expense }\end{array}$ & $19,628.10$ \\
\hline & & & Total & $800,993,655.75$ \\
\hline
\end{tabular}

Abbreviations: British pound sterling (GBP), Italian lira (ITL), Swedish krona (SEK), Swiss franc (CHF), United States dollar (USD).

Source: Gilbert I925, pp. II-I2.

J. P. Morgan, whose correspondence with Hans Luther demonstrated the Germans eagerness to accept an international loan. ${ }^{57}$ Payments of the principal and interest would have then mainly derived from Germany's reformed customs and taxation systems, the proceeds from which acted as collateral security (Clement 2004, p. 34). The loan itself aimed to compensate for the Reichsbank's depleted gold reserves and provide a temporary foundation for Germany to fulfil its initial reparation payments (Clarke I967, p. 49).

An estimated 34,440 investors in each of the represented countries subscribed to the new external Loan (compared to 8,350 investors of the Austrian loan of I923) (Costigliola I976, p. 495; Dunlap 2016, p. I78). An American partner at J. P. Morgan \& Co., Dwight Morrow, wrote that foreigners invested in German bonds 'not only because the interest rate was attractive and the principal seemed

57 Register of the Henry Mauris Robinson Papers, I9I7-I936 (4300I), Hoover Institution, Stanford University [henceforth HMR], '[Letter to] His Excellency Dr. Luther, Minister of Finance of the German government' (Io Oct. I924), box 27, folder I, 2. 
secure, but because they felt that they were thus associated themselves in a fine venture to help Europe back on her feet' (I927, pp. 225-6). Perhaps more convincingly, commercial claims on Germany also had more seniority than reparation payments, and so lending to Germany appeared relatively safe (Ritschl 2012, p. 952). American creditors were also relieved that the German government had undertaken steps to regulate its borrowing (McNeil I986, p. 68). Indeed, the presence of American advisers in the reform process most likely created 'a favorable impression [among] American bankers and investors ... [who] facilitate[d] the borrowing of money by the [German] government in the American market' (Kemmerer I927, p. 4).

The provision guaranteeing investor protection dictated that reparation payments were only to be made if they did not destabilise the exchange rate. Criticisms of this protection clause have highlighted the fact that the Germans benefited from some relief from (or avoidance of) reparation payments (Ritschl 20I4, p. 208). But, in the endeavour to ensure Germany's equal footing with the rest of Europe, the advisers found investor protection preferable. Not only was the principle of investor protection beneficial to the banking community (Ritschl 20I2, p. 953) and popular among trade union leaders (James I986, p. 203), but it also ensured the stability of the currency. For the advisers, the Transfer Office fulfilled this role, as it remained 'in permanent contact with the money market'. ${ }^{58}$ It was not the case that the 'economics of transfers remained imperfectly understood at this time' (Schuker I988, p. 40), but the concerns of the advisers lay elsewhere. The rationale behind investor production focused less on assuaging moral hazard and more on ensuring that capital inflows did not destabilise the currency. ${ }^{59}$ Thus, the loan and transfer protection worked alongside the railway and tax reforms, improving the financial state of Germany and stabilising the political tensions of Europe.

\section{I}

For contemporary onlookers, the plan seemingly failed. Charles Rist, a director at the Bank of France, expressed concerns over the short-term outlook of the Dawes Plan: 'The year I925 [the first full year of the Plan] did not solve the question of allied debts ... leaving everything to be settled in the future' (I926, p. 277). Even for Americans, such as Harold Moulton, an economist at the Brookings Institution, the plan lacked clarity on how much Germany needed to pay and left the Ruhr occupation unaddressed (I924, pp. I I6-23). Yet, as this article strives to show, the financial reforms played a 'critical role' in addressing 'fears [that hyperinflation] would prove self-fulfilling' (Eichengreen I992, p. I 50). They 'shielded the German economy from large reparations

58 BSC, 'Proposal by M. Houtart concerning the question of transfers in note no. 4 submitted by Sir Josiah Stamp' (9 Feb. I924), box 4, folder I4, 'Capacity to Pay', I.

59 BSC, 'Effect of reparation payments on currency stability' (26 Jan. I924), box 3, folder I, 'Edwin Kemmerer Memoranda', I-4. 
demands during the projected recovery period ... [and] sheltered the Reich government from an immediate budgetary drain' (Schuker I988, pp. 23-4). The German administration succeeded in achieving some fiscal stabilisation, albeit temporarily, through tax increases and reductions in public expenditures. Indeed, the plan appeared to offer 'the last and only hope for restoration of world financial stability' (McNeil I986, p. 32). To call the plan a failure is to underestimate the reforms' implications for central banking, money doctoring, economic theories of transfers and the international balance of power. As Gilbert remarked, in order ' $[t]$ o understand the Experts' Plan one must see it in its historical setting. It is necessary to look back to the conditions that preceded its adoption and to remember the situation that it was intended to meet' (I926, p. ii).

Certain scholars have criticised how the plan addressed economic rather than military affairs (Link I970, p. 246; Fischer 2003, pp. 285-6). Indeed, its duration was not specified and it 'left many delicate issues unresolved' because it remained unclear as to how capital should have been distributed between the state and private businesses (Schuker I976, p. I74; Marks I978, p. 247). But the approach of the advisers called for overarching banking reforms, which instigated the later Franco-Belgian withdrawal from the Ruhr. The strategic avoidance of the topic ironically allowed the plan to have an even stronger effect. It preceded territorial agreements, namely the Locarno Treaties, by enacting much needed financial reform. While it did not constitute the definitive solution to all interwar predicaments, as proposed at the London Conference, the plan provided foundational components to Germany's future economic recovery: ${ }^{60}$ the creation of the Golddiskontbank (which effectively became a subdivision of the Reichsbank) and budgetary reform (Schotz 1987, p. I63).

Financial reforms, in a way, succeeded in addressing military concerns. Kemmerer and Young knew that any direct mention of a military withdrawal would not have been accepted, and instead opted to facilitate reparation payments through the banking system, thereby removing the Franco-Belgian justification for the occupation. The plan set the general post-I924 framework for European financial affairs, as it convinced the French delegation to accept a new reparation payments schedule and served to resolve the geopolitical questions by concentrating on economic incentives. Chancellor Heinrich Brüning, in the foreword to Dawes' diaries, hinted that Dawes 'restricted the Committee's discussions of the Ruhr problem to its purely economic aspects', which helped the committee gain support from the Belgian, French and British governments. ${ }^{61}$ More importantly, it bought additional time for those interested in seeing the economic reconstruction of Europe through American credit (Ritschl I999, p. I43). At the intersection of economics and politics, the technical advisers were essential parts of the process of banking reform (Flandreau 2003, p. 4)

A study of the perspectives, intentions and theories of these economic advisers sheds additional light on the nature of interwar geopolitical and economic diplomacy.

\footnotetext{
60 'Première séance plénière', pp. I I-I2.

61 Heinrich Brüning, 'Foreword', in Dawes I939, pp. xxvi-xxvii.
} 
Contemporary understandings of currency and central-banking reforms in particular made clear that, under proper fiscal and monetary conditions, Germany would have been able to achieve long-term stability in spite of the reparations bill. With regard to the plan's long-term legacy, Denise Artaud asserted that it challenged the theory of American isolationism in the I920s, while Frank Costigliola viewed American foreign economic policy as 'selectively interventionist' (Costigliola I977, p. 477; Artaud I979, p. 365). Yet the role of the American economic advisers showed that the US remained heavily invested in financial markets. Although the US was perhaps 'a limited participant in European affairs', the German delegation viewed it as 'a bulwark against France's possible manipulation of reparations claims' (Schuker I976, p. I75). Looking at the advisers' reports and proposals complicates this narrative on the role of American capital in Europe, demonstrating how economists considered geopolitical tensions throughout their deliberations on financial reforms.

'[T]he reconstruction of Germany was not an end in itself, Agent General Gilbert proclaimed at the aforementioned Council on Foreign Relations dinner, 'but was only part of the larger problem of the reconstruction of Europe' (I926, p. xii). By establishing a central bank of issue, providing a stabilisation loan and setting a five-year reparations schedule, the plan was the culmination of efforts from businessmen, economists and governments acting with different interests but with a similar goal in mind. In the process, the committee and its advisers thus fulfilled a certain role within the diplomatic agenda of the Allied countries. They found that a potential solution to the geopolitical tensions in Europe could have been a more integrated economy, a theme which has continued to pervade the discourse on European and, indeed, global affairs. While each delegate proposed a series of reforms that seemed most pressing, the economic advisers provided the foundation for both contemporary and current understandings of monetary reform. By opening domestic markets to foreign capital and restructuring the annuity payments of Germany, the Dawes Plan initiated financial reform as a means of promoting the possibility of peace.

Submitted: I4 March 2019

Revised versions submitted: 3 August 2019; 9 October 2019

Accepted: Io October 2019

First published online: 26 December 2019

\section{Archives}

Alan Gustavus Goldsmith Letters (24002), Hoover Institution Archives, Stanford University

Benjamin Strong Collection (MCi28), Department of Rare Books and Special Collections, Princeton University

Edwin W. Kemmerer Papers (MCI46), Department of Rare Books and Special Collections, Princeton University

Register of the Arthur N. Young Papers (66005), Hoover Institution Archives, Stanford University

Register of the Henry Mauris Robinson Papers (4300I), Hoover Institution Archives, Stanford University 


\section{Sources}

AGL. '[Letter to Chris A. Herter]' (I7 Mar. I924), folder I, 'Committee of Experts of the Reparations Commission'.

AGL. '[Letter to Chris A. Herter]' (20 Jan. 1924), folder I, 'Committee of Experts of the Reparations Commission'.

AGL. '[Letter to Chris A. Herter]' (24 Feb. I924), folder I, 'Committee of Experts of the Reparations Commission'.

AYP. Arthur Young, '[Diary entry]' (I2 Mar. 1924), box I, folder I, 'Reparations and the Reparations Commission, I9I8-I934'.

AYP. Arthur Young, '[Diary entry]' (2 Apr. 1924), box I, folder I, 'Reparations and the Reparations Commission, I9I 8-I934'.

AYP. Arthur Young, '[Diary entry]' (2 Feb. I924), box I, folder I, 'Reparations and the Reparations Commission, I9I 8-I934'.

AYP. Arthur Young, '[Diary entry]' (5 Feb. I924), box I, folder I, 'Reparations and the Reparations Commission, I9I 8-I934'.

AYP. Arthur Young, '[Diary entry]' (8 Apr. I924), box I, folder I, 'Reparations and the Reparations Commission, I9I 8-1934'.

AYP. 'German Gold Discount Bank' (25 Apr. 1924), box 3, folder 5, 'German Currency and Banking, I923-I924'.

AYP. 'The Golddiskontbank' (29 Mar. 1924), box 3, folder 5, 'German Currency and Banking, I923-I924'.

BSC. 'Effect of reparation payments on currency stability' (26 Jan. I924), box 3, folder I, 'Edwin Kemmerer Memoranda'.

BSC. E. W. Kemmerer, '[Rough draft of] Suggestions as basis for discussion concerning the control of the proposed new bank' (30 Jan. I924), box 3, folder I, 'Edwin Kemmerer Memoranda'.

BSC. E. W. Kemmerer, 'Can stability of a currency be attained and retained without a balanced budget?' (22 Jan. I924), box 3, folder I, 'Edwin Kemmerer Memoranda'.

BSC. E. W. Kemmerer, 'Outline of plan for proposed German Bank, prepared to suggest a positive form: topics for discussion' (26 Jan. I924), box 3, folder I, 'Edwin Kemmerer Memoranda'.

BSC. E. W. Kemmerer, 'Tentative balance sheet of proposed new bank at time of opening for business' (30 Jan. I924), box 3, folder I, 'Edwin Kemmerer Memoranda'.

BSC. E. W. Kemmerer, 'The desirability of a unified currency in Germany' (22 Jan. I924), box 3, folder I, 'Edwin Kemmerer Memoranda'.

BSC. E. W. Kemmerer and J. S. Davis, 'Is a balanced budget necessary for currency stability?' (25 Jan. I924), box 3, folder I, 'Edwin Kemmerer Memoranda'.

BSC. Émile Francqui, 'Report by M. Francqui' (6 Feb. I924), box 4, folder I5, 'Capacity to Pay'.

BSC. Maurice Frère, 'Comparison of the public debts of Germany. Belgium, France, Great Britain and Italy' (25 Jan. I924), box 4, folder I 5 , 'Capacity to Pay'.

BSC. Maurice Houtart, 'Elasticity of the German budget' (7 Feb. 1924), box 4, folder I 5 , 'Capacity to Pay'.

BSC. 'Proposal by M. Houtart concerning the question of transfers in note no. 4 submitted by Sir Josiah Stamp' (9 Feb. I924), box 4, folder I4, 'Capacity to Pay'.

BSC. Sir Josiah Stamp, 'How soon can the budget position respond to currency stabilisation?' (I I Feb. I924), box 4, folder I5, 'Capacity to Pay'.

BSC. 'The proposal to create a gold credit bank: statements made by Dr. Schacht to the Reichstag Commission' (I2 Mar. I924), box 4, folder I4, 'Gold Bank'.

EKP. 'Address by General Charles G. Dawes, American Member and President of the First Committee of Experts of the Reparations Commission, at the opening session of the First Committee of Experts', box I64, folder 2, 'Dawes Committee Memoranda - General, I924'.

EKP. 'Material for a study of Germany's economy, currency and finance, by order of the German government', box I64, folder I, 'Currency, I924-I926'.

EKP. 'Memorandum for Mr. Dawes: plan for the new gold Bank of Issue in Germany'. (20 Feb. I924), box I64, folder 9, 'Dawes Committee Memoranda - Dawes Committee Papers, I924'.

EKP. 'Memorandum for Mr. Dawes: principal features of plan for new Bank of Issue' (I I Feb. I924), box I64, folder 9, 'Dawes Committee Memoranda - Dawes Committee Papers, I924'. 
EKP. 'The reparations problem and the Dawes Report' (I924), box I65, folder 4, 'Dawes Report'. HMR. '[Letter to] His Excellency Dr. Luther, Minister of Finance of the German government' (Io Oct. I924), box 27 , folder I.

Le Temps (1924).

\section{References}

Agreement between the Reparation Commission and the German government. American Journal of International Law, 19, pp. 24-36 (I925).

AHAMED, L. (2009). Lords of Finance: The Bankers Who Broke the World. London: Penguin Books.

ARTAUD, D. (I979). La question des dettes interalliées et la reconstruction de l'Europe. Revue Historique, 26I, pp. 363-82.

BALDERSTON, T. (2002). Economics and Politics in the Weimar Republic. Cambridge: Cambridge University Press.

BARIÉTY, J. (1998). France and the politics of steel, from the Treaty of Versailles to the International Steel Entente, I919-1926. In R. Boyce (ed.), French Foreign and Defence Policy, 1918-1940: The Decline and Fall of a Great Power. London: Routledge.

BOYDEN, R. W. (I924). The Dawes Report. Foreign Affairs, 2, pp. 583-97.

CALMETTE, G. (1924). Recueil de documents sur l'histoire de la question des réparations (1919-5 Mai 1921), ed. G. Calmette. Paris: Ancienne Librairie Schleicher.

ClARKE, S. V. O. (1967). Central Bank Cooperation 1924-31. New York: Federal Reserve Bank of New York.

CLEMENT, P. (2004). 'The touchstone of German credit': Nazi Germany and the service of the Dawes and Young Loans. Financial History Review, II, pp. 33-50.

COSTIGLIOLA, F. C. (1976) The United States and the reconstruction of Germany in the I920s. The Business History Review, 50(4), pp. 477-502.

COSTIGLIOLA, F. C. (I977) Anglo-American financial rivalry in the I920s. Journal of Economic History 37, pp. 9 I I -34 .

DAVIS, J. S. (1920). World currency expansion during the war and in I919. Review of Economics and Statistics, 2, pp. 8-20.

DAVIS, J. S. (I92 I). World banking, currency, and prices, I920-2I. Review of Economics and Statistics, 3, pp. $304-25$.

DAWES, C. G. (1924). Lettre du Président: à la Commission des Réparations. Rapport du Premier Comité d'Experts. Paris: s.n.

DAWES, C. G. (1939). A Journal of Reparations. London: Macmillan and Co.

DEPOORTERE, R. (1997). La question des réparations allemandes dans la politique étrangère de la Belgique après la Première Guerre Mondiale, 1919-1925. Gilly: Académie Royale de Belgique.

DUNLAP, A. B. (2016). Charles Gates Dawes: A Life. Evanston: Northwestern University Press.

EICHENGREEN, B. (1992). Golden Fetters: The Gold Standard and the Great Depression, 1919-1939. New York: Oxford University Press.

FELDMAN, G. D (1997). The Great Disorder: Politics, Economics, and Society in the German Inflation, 1914-1924. Oxford: Oxford University Press.

FELDMAN, G. D. (2005). The reparations debate. Diplomacy and Statecraft, I6, pp. 487-98.

FISCHER, C. (2003). The Ruhr Crisis, 1923-1924. Oxford: Oxford University Press.

FISCHER, C. (2005). Scoundrels without a fatherland? Heavy industry and transnationalism in post-First World War Germany. Contemporary European History, I4, pp. 44I-64.

FISCHER, C. (2017). A Vision of Europe: Franco-German Relations during the Great Depression, 1929-1932. Oxford: Oxford University Press.

FISHER, I. (1933). The debt-deflation theory of Great Depressions. Econometrica, I, pp. 337-57.

FLANDREAU, M. (2003). Introduction: money and doctors. In Marc Flandreau (ed.), Money Doctors: The Experience of International Financial Advising 1850-2000. London: Routledge.

GILBERT, S. P. (I925). Report of the Agent General for reparation payments. In The Execution of the Experts' Plan. Berlin: The Office for Reparation Payments.

GILBERT, S. P. (I926). The meaning of the 'Dawes Plan'. Foreign Affairs, 4, pp. i-xii 
HOLTFRERICH, C.-L. (1980). Die deutsche Inflation 1914-1923: Ursachen und Folgen in internationaler Perspektive. Berlin: Walter de Gruyter.

JAMES, H. (1985). The Reichsbank and Public Finance in Germany, 1924-1933: A Study of the Politics of Economics during the Great Depression. Frankfurt am Main: Fritz Knapp Verlag.

JAMES, H. (1986). The German Slump: Politics and Economics, 1924-1936. Oxford: Clarendon Press.

JAMES, H. (I987). Die Währungsstabilisierung I923/24 in internationaler Perspektive. In Werner Abelshauser (ed.), Die Weimarer Republik als Wohlfahrtsstaat. Stuttgart: Franz Steiner Verlag.

JAMES, H. (I992). Financial flows across frontiers during the interwar depression. Economic History Review, 45, pp. 594-6г 3.

JEANNESSON, S. (I996). Pourquoi la France a-t-elle occupé la Ruhr? Vingtième Siècle. Revue d'histoire, 5I, pp. 56-67.

JEANNESSON, S. (1998). Poincaré, la France et la Ruhr (1922-1924): Histoire d'une occupation. Strasbourg: Presses Universitaires de Strasbourg.

KEMMERER, E. W. (I925). The burden of Germany's obligations under the Dawes Plan. Annals of the American Academy of Political and Social Science, I20, pp. 7-IO.

KEMMERER, E. W. (I927). Economic advisory work for governments. American Economic Review, I7, pp. I-I 2 .

KEYNES, J. M. (I920). The Economic Consequences of the Peace. London: Macmillan and Co.

KINDLEBER GER, C. P. (I973). The World in Depression, 1929-1939. Berkeley: University of California Press.

KLEINSCHMIDT, C. (2004). Rekonstruktion, Rationalisierung, Internationalisierung: aktive Unternehmensstrategien in Zeiten des passiven Widerstandes. In G. Krumeich and J. Schröder (eds.), Der Schatten des Weltkriegs: Die Ruhrbesetzung 1923. Essen: Klartext Verlag.

KRÜGER, P. (I98I). Das Reparationsproblem der Weimarer Republik in fragwürdiger Sicht: kritische Überlegungen zur neuesten Forschung. Vierteljahrshefte für Zeitgeschichte, 29, pp. 2 I-47.

LINK, W. (1970). Die amerikanische Stabilisierungspolitik in Deutschland, 1921-1932. Düsseldorf: Droste Verlag.

MAIER, C. S. (I975). Recasting Bourgeois Europe: Stabilization in France, Germany, and Italy in the Decade after World War I. Princeton, NJ: Princeton University Press.

MARKS, S. (I969) Reparations reconsidered: a reminder. Central European History, 2, pp. 356-65.

MARKS, S. (1978). The myths of reparations. Central European History, II, pp. 23 I-55.

MARKS, S. (2003). The Illusion of Peace: International Relations in Europe 1918-1933. Basingstoke: Palgrave.

MCNEIL, W. C. (1986). American Money and the Weimar Republic: Economics and Politics on the Eve of the Great Depression. New York: Columbia University Press.

MIERZEJEWSKI, A. C. (I999). The Most Valuable Asset of the Reich: A History of the German National Railway, vol. I: 1920-1932. Chapel Hill: University of North Carolina Press.

MINISTERE DES AFFAIRES ÉTRANGÈRES (I924). Documents diplomatiques relatifs aux réparations. Brussels: Imprimerie Lesigne.

MORROW, D. W. (I927). Who buys foreign bonds? Foreign Affairs, 5, pp. 219-32.

MOUltON, H. G. (I924). The Reparation Plan: An Interpretation of the Reports of the Expert Committees Appointed by the Reparation Commission, November 30, 1923. New York: McGraw-Hill.

MÜLLER, C. and BUSCH, U. (2005). The new German transfer problem. Jahrbuch für Wirtschaftswissenschaften / Review of Economics, 56, pp. 285-304.

ORDE, A. (I990). British Policy and European Reconstruction after the First World War. Cambridge: Cambridge University Press.

O'RIORDAN, E. (200I). Britain and the Ruhr Crisis. Basingstoke: Palgrave.

PARMENTIER, J. (I924). The reparations problem after London. Foreign Affairs, 3, pp. $244-52$.

PATTERSON, E. M. (I924). The Dawes Report and after. Annals of the American Academy of Political and Social Science, II4, pp. IO-4.

PÉTERI, G. (I992). Central bank diplomacy: Montagu Norman and central Europe's monetary reconstruction after World War I. Contemporary European History, I, pp. 233-58.

POHL, M. and SCHNEIDER, A. H. (I999). Die Rentenbank: Von der Rentenmark zur Förderung der Landwirtschaft, 1923-1949-1999. Munich: Piper Verlag. 
REPARATIONS COMMISSION (1924). Rapport du premier comité d'experts. Rapport du Premier Comité d'Experts. Paris: s.n.

RIST, C. (I926). Les dettes interalliées et les réparations. Revue d'économie politique, 40, pp. 345-5I.

RITSCHL, A. (I999). Les réparations allemandes, I920-I933: une controverse revue par la théorie des jeux. Économie Internationale, 78, pp. I29-54.

RITSCHL, A. (20I2). The German transfer problem, I920-33: a sovereign-debt perspective. European Review of History, I9, pp. 943-64.

RITSCHL, A. (2014). Deutschlands Krise und Konjunktur 1924-1934: Binnenkonjunktur, Auslandsverschuldung und Reparationsproblem zwischen Dawes-Plan und Transfersperre. Berlin: Walter de Gruyter.

ROSENBERG, E. S. (1985). Foundations of United States international financial power: gold standard diplomacy, I900-1905. The Business History Review, 59, pp. 169-202.

SARGENT, T. J. (20I3). Rational Expectations and Inflation. Princeton: Princeton University Press.

SAUVY, A (1984). Histoire économique de la France entre les deux guerres, vol. 3. Paris: Economica.

SCHACHT, H. (1927). Die Stabilisierung der Mark. Berlin and Leipzig: Deutsche Verlags-Anstalt Stuttgart.

SCHACHT, H. (1953). 76 Jahre meines Lebens. Bad Wörishofen: Kindler und Schiermeyer Verlag.

SCHOTZ, H. O. (1987). Der Kampf um die Mark 1923/24: Die Deutsche Währungsstabilisierung unter dem Einfluss der nationalen Interessen Frankreichs, Großbritanniens und der USA. Berlin: Walter de Gruyter.

SCHUKER, S. A. (1976). The End of French Predominance in Europe: The Financial Crisis of 1924 and the Adoption of the Dawes Plan. Chapel Hill: University of North Carolina Press.

SCHUKER, S. A. (1988). American 'Reparations' to Germany, 1919-33: Implications for the Third-World Debt Crisis. Princeton, NJ: International Finance Section, Department of Economics, Princeton University.

SCHUKER, S. A. (2003). Money doctors between the wars: the competition between central banks, private financial advisers, and multilateral agencies, I919-39. In Marc Flandreau (ed.), Money Doctors: The Experience of International Financial Advising 1850-2000. London: Routledge.

SCHWABE, K. (I979). Reparation at the Paris Peace Conference, and political economy versus national sovereignty: comment on Trachtenberg and McDougall. Journal of Modern History, 5I, pp. 68-73.

TRACHTENBERG, M. (1979). Reparation at the Paris Peace Conference. Journal of Modern History, 5I, pp. 24-55.

TRACHTENBERG, M. (I980). Reparation in World Politics: France and European Economic Diplomacy, 1916-1923. New York: Columbia University Press.

WRIGHT, J. (2002). Gustav Stresemann: Weimar's Greatest Statesman. Oxford: Oxford University Press.

WUESCHNER, S. A. (I999). Chartering Twentieth-Century Monetary Policy: Herbert Hoover and Benjamin Strong, 1917-1927. Westport, CT: Greenwood Press. 